\title{
Nooit meer slapen? Over deregulering en verantwoording
}

Citation for published version (APA):

Koedijk, C. G. (1994). Nooit meer slapen? Over deregulering en verantwoording. Datawyse / Universitaire Pers Maastricht. https://doi.org/10.26481/spe.19940324ck

Document status and date:

Published: 24/03/1994

DOI:

10.26481/spe.19940324ck

Document Version:

Publisher's PDF, also known as Version of record

\section{Please check the document version of this publication:}

- A submitted manuscript is the version of the article upon submission and before peer-review. There can be important differences between the submitted version and the official published version of record.

People interested in the research are advised to contact the author for the final version of the publication, or visit the DOI to the publisher's website.

- The final author version and the galley proof are versions of the publication after peer review.

- The final published version features the final layout of the paper including the volume, issue and page numbers.

Link to publication

\footnotetext{
General rights rights.

- You may freely distribute the URL identifying the publication in the public portal. please follow below link for the End User Agreement:

www.umlib.nl/taverne-license

Take down policy

If you believe that this document breaches copyright please contact us at:

repository@maastrichtuniversity.nl

providing details and we will investigate your claim.
}

Copyright and moral rights for the publications made accessible in the public portal are retained by the authors and/or other copyright owners and it is a condition of accessing publications that users recognise and abide by the legal requirements associated with these

- Users may download and print one copy of any publication from the public portal for the purpose of private study or research.

- You may not further distribute the material or use it for any profit-making activity or commercial gain

If the publication is distributed under the terms of Article $25 \mathrm{fa}$ of the Dutch Copyright Act, indicated by the "Taverne" license above, 


\title{
mE \\ $\checkmark A B$ \\ 591
}

\section{NOOIT MEER SLAPEN?}

Over deregulering en verantwoording

\author{
Rede
}

in verkorte vorm uitgesproken bij de aanvaarding van het ambt van hoogleraar Bedrijfseconomie, in het bijzonder

Finance and Econometrics, aan de Rijksuniversiteit

Limburg op donderdag 24 maart 1994

door

Dr. C.G. Koedijk

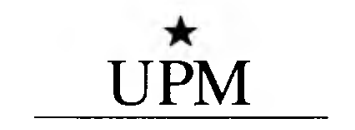

UNIVERSITAIRE PERS MAASIRICHT 
I like economics, said Marvin, especially the technical side, but perhaps I can also do some good in the world. Excellent, said Professor Grierson, but watch that business about doing good. It's fine in principle, but a smart economist sticks to his knitting. 
Mijnheer de Rector Magnificus,

Zeer gewaardeerde toehoorders,

\section{Inleiding}

Het afgelopen jaar was het jaar van Zuidoost-Azië. Een onderzoek van de Wereldbank meldde dat de economieën van de landen uit deze regio een aanmerkelijk groter deel van de wereldproduktie voor hun rekening nemen dan tot voor kort werd gedacht. Ook niet onbelangrijk is dat het totale groeipercentage van de regio de $7 \%$ overtrof. Misschien de meest veelbetekenende anwijzing is dat een gerenommeerd weekblad als The Economist niet meer alleen de economische kerncijfers van de westerse landen publiceert, maar ook een aparte sectie toevoegt die gewijd is aan het wel en wee van, onder andere, Zuidoost-Azië. Het is allemaal een gevolg van de globalisering' van de wereldproduktie: het proces waarbij de deelactiviteiten in de produktieketen naar de meest kostenefficiënte, geografische combinatie verplaatst worden. Landen in Zuidoost-Azië zijn in toenemende mate in staat hun kostenvoordelen uit te buiten en te concurreren met de westerse landen. Zelfs universiteiten hebben indirect met dit proces van globalisering te maken. Wetenschappelijke tijdschriften kwamen tot voor kort dicht bij huis tot stand, maar een tijdschrift zoals de Journal of Empirical Finance, dat in deze faculteit in Maastricht wordt geredigeerd, wordt getypt en gezet in India, gedrukt in Schotland, en wordt wereldwijd verspreid.

De enorme groeidynamiek in Zuidoost-Azië en de sterk toegenomen wereldwijde concurrentie vormen een schril contrast met de situatie in Europa en vooral in Nederland. In dit deel van de wereld blijven niet alleen de economische groei en de concurrentiekracht achter, maar neemt bovendien de werkloosheid in snel tempo toe. Typerend voor

${ }^{1}$ Zie hierover ook J.E. Andriessen en R.F. van Esch (1993). 
de werkloosheid in Nederland is haar permanente karakter: snel omhoog en niet of heel moeizaam weer naar beneden. In Nederland bereiken we naar alle waarschijnlijkheid dit jaar een werkloosheid van circa 700.000 personen. Als belangrijkste instrument om de stijgende werkloosheid te keren hamert de overheid op loonmatiging. Gezien het aanvankelijke succes hiervan in de jaren tachtig is dat alleszins begrijpelijk. Op korte termijn heeft loonmatiging immers het voordeel dat de kostenstijging van arbeid binnen de perken gehouden wordt. Helaas staat daar op lange termijn tegenover dat langdurige loonmatiging leidt tot verstarring van het loongebouw, tot minder groeidynamiek en tot het achterblijven van de inkomensontwikkeling in Nederland. In de afgelopen tien jaar is het inkomen per hoofd van de bevolking in Nederland jaarlijks gestegen met gemiddeld $1.3 \%$, terwijl het EG-gemiddelde over deze periode gemiddeld met $2.0 \%$ toenam. Dit betekent dat de Nederlander in die periode ruim $8 \%$ minder is gaan verdienen dan zijn EG-buren. De negatieve effecten van dit eenzijdig op loonmatiging gerichte beleid lijken alleen op te vangen indien de overheid in haar macro-economisch beleid streeft naar belastingverlaging en over een breed front meer marktwerking, meer concurrentie en vooral een sterkere economische structuur creëert. Naast sterk concurrerende sectoren die handelen met het buitenland, bestaan er in Nederland immers binnenlandse sectoren waar sprake is van weinig of geen concurrentie en te veel overheidsbemoeienis. ${ }^{2}$ Vaak is daarbij sprake van kartelvorming, en daarmee van hogere prijzen, verminderde kwaliteit en slechtere voorzieningen. Meestal wordt het gebrek aan concurrentie in stand gehouden door overheidsregulering. Bekend zijn bijvoorbeeld de overheidsbemoeienis met de vestigingswet, de mededinging, de werking van de arbeidsmarkt, het subsidiebeleid van de overheid en het overheidsmanagement. Maatregelen op deze terreinen zijn vaak ontworpen als bescherming voor de zwakkeren in de samenleving: de laagstbetaalden, de consument, de kleine producent. Over tijd zijn ze echter verworden tot een deken die de

2 Zie hierover ook het speciale nummer van ESB 'Het einde van het kartelparadijs', 23 september 1992. 
economie in slaap wiegt en op den duur verstikt. Meer marktwerking en deregulering over een brede linie zou in deze sectoren voor nieuwe dynamiek kunnen zorgen en na verloop van tijd kunnen leiden tot meer groei, hogere kwaliteit en hogere inkomens. De analyse dat het macro-economisch beleid dient te worden aangevuld met meer marktwerking en deregulering is verre van nieuw en wordt reeds enkele jaren van verschillende zijden naar voren gebracht. Instanties als bijvoorbeeld de Organisatie voor Economische Samenwerking en Ontwikkeling in Parijs maken zich al jaren sterk voor deregulering ${ }^{3}$ van de Nederlandse economie. Ondanks de eensluidendheid in de analyse blijkt het in de praktijk enorm moeilijk om systematisch minder overheidsbemoeienis en meer deregulering te realiseren.

Veranderingsprocessen in Nederland gaan zeer traag en soms lijkt het erop dat grote delen van de maatschappij opteren voor de winterslaap. Recentelijk karakteriseerde Knapen (1993), hoofdredacteur van het NRC Handelsblad, dit proces als 'demosclerose' en vatte het als volgt samen: "Zowel in de wereld van de wetenschap als in de wereld van de vrije markteconomie wordt vooruitgang geboekt via de methode van Trial and Error. Men zet een stap, probeert varianten uit, heeft succes, faalt, corrigeert en komt zo een stap voorwaarts. Van dit instrumentarium is de overheid praktisch beroofd. Elke vernieuwing schept haar eigen belangengroep en die wordt en blijft een factor, ook al weet iedereen dat de vernieuwing van gisteren het blok aan het been van morgen wordt". Dit proces wordt nog versterkt door het allesoverheersende streven van de politiek om de burgers voortdurend tevreden te stellen in plaats van te fungeren als een betrouwbare partner die ook zijn beperkingen heeft. Knapen (1993) vatte het als volgt samen: "Mensen eisen van de regering dat deze hen gelukkig maakt. Of het nu gaat om welvaart, welzijn, welbevinden in geestelijke en lichamelijke zin - elke dag stelt het politici voor keuzes met minimale speelruimte. Hun legitimatie is gebaseerd op de vervulling

${ }^{3}$ Zie hierover ook Bomhoff (1988) en Kremers (1991). 
van telkens nieuwe verlangens en zo praten politici met het oog op herverkiezing dan ook". Al gauw ontstaat dan het beeld van een overbelaste overheid die geen partij is voor de calculerende burger met zijn of haar deelbelang. Naar mijn mening wordt het huidig gebrek aan dynamiek van de Nederlandse economie vooral in de hand gewerkt door het gebrekkige inzicht in de kosten en baten van overheidsregulering. Door dit gebrekkige inzicht is de overheid in onvoldoende mate in staat belangen- en pressiegroepen weerwerk te leveren en bereikt zij de publieke opinie niet of in onvoldoende mate. De behoefte aan beter inzicht in kosten en baten van het overheidsbeleid vindt zijn weerspiegeling in het toegenomen aantal parlementaire enquêtes van de afgelopen jaren. Het centrale thema van dit betoog is dat er weinig reden is om te verwachten dat de overheid uit zichzelf de burger die kosten en baten gaat voorrekenen en dat er dus langs institutionele weg naar versterking van deze taak van de overheid gezocht moet worden. Als de overheid beter tegen de verschillende deelbelangen is opgewassen doordat ze aan bepaalde voorzieningen en diensten een prijskaartje kan hangen, is er ook meer uitzicht op een verbetering van de groeidynamiek van de Nederlandse economie.

\section{De politieke economie van structurele aanpassingen}

Indien we willen begrijpen waarom het zo moeilijk is om structurele veranderingen door te voeren, dan is naast kennis en analyse van het economische proces ook kennis van het politieke proces vereist. Er is, met andere woorden, inzicht in de politieke economie van structurele aanpassingen nodig. De analyse van structurele aanpassingen staat in de economische theorie nog in de kinderschoenen. Wel zijn er belangrijke aanzetten, die zijn gebaseerd op de belangengroepenbenadering van Buchanan $(1984)$ en Olson $(1982,1984)$ en deels op recente analytische bijdragen van onder anderen Stigler (1971), Alesina en Drazen (1991), Laffont en Tirole (1993) en Rodrik (1993). Verder zijn

${ }^{4}$ Zie hierover ook Wolfson (1993). 
ze gebaseerd op de ervaringen die in het recente verleden in een aantal landen zijn opgedaan met structurele veranderingen.

Kennis van de politieke economie van structurele veranderingen begint met de belangengroepenbenadering. Belangen- of pressiegroepen staan aan de basis van rigiditeiten. Zoals in het werk van Nobelprijswinnaar Buchanan en het werk van Olson reeds uitvoerig is aangetoond, lijden de meeste westerse economieën aan de kwaal dat in de loop van de tijd steeds meer belangengroepen en coalities door middel van belangenbehartiging voordelen voor zichzelf proberen te realiseren ten koste van het algemeen belang en de welvaart van de samenleving. Olson verwoordde het in zijn beroemde boek The Rise and Decline of Nations (1982) als volgt: "Stable societies with unchanged boundaries tend to accumulate more collusions and organizations for collective action". Vaak helpt de overheid hierbij door regelgeving uit te vaardigen die gericht is op het bewaken van de kwaliteit van de voorziening of het aangeboden produkt. Na verloop van tijd verliest de regelgeving zijn waarde, maar wordt toch gehandhaafd omdat de belangengroepering de regels weet te presenteren als een verworven recht, met als netto resultaat monopolistische marktstructuren, maatschappelijke verstarring en minder economische groei. In de woorden van Olson: "Distributional coalitions make decisions more slowly than the individuals and the firms of which they are comprised, tend to have crowded agendas and bargaining tables, and more often fix prices than quantities", en "Distributional coalitions slow down a society's capacity to adopt new technologies and to reallocate resources in response to changing conditions, and thereby reduce the rate of economic growth".

Olson (1982) geeft aan dat het doorbreken van die maatschappelijke blokkades doorgaans alleen mogelijk is onder uitzonderlijke omstandigheden zoals revoluties, oorlogen of opstanden. Bekend in dit opzicht zijn met name de ervaringen in Latijns-Amerika. Onder minder extreme omstandigheden is het veel moeilijker om de blokkades van belangengroepen te doorbreken en betekent dit vaak een langdurig 
politiek debat met een onzekere uitkomst. Dit proces is recent analytisch gemodelleerd door Fernandez en Rodrik (1991). In hun werk laten zij zien dat onzekerheid over wie als winnaar of verliezer uit het aanpassingsproces naar voren zal komen, tot een algemene blokkade van veranderingsprocessen leidt. Laffont en Tirole (1993) benadrukken in hun recente boek $A$ Theory of Incentives in Procurement and Regulation onder andere het belang van instituties als mechanisme voor het op gang houden en controleren van veranderingsprocessen: "Institutions matter because the ultimate principals - the people cannot design a complete contract or grand mechanism governing the behavior of regulated firms, regulators, politicians and interest groups", en "Institutions serve to curb regulatory abuse by prohibiting the use of those institutions that are most prone to be misused, by creating checks and balances and by enlisting watchdogs".

In de recente theoretische literatuur komt voorts het belang van voldoende steun van de publieke opinie naar voren. ${ }^{5}$ Het belang van dit laatste element wordt onderstreept door de recente praktijkervaringen in Nieuw-Zeeland. Vóór 1985 had Nieuw-Zeeland een van de meest gereguleerde economieën van de westerse wereld. Als gevolg hiervan was het inkomen per capita in Nieuw-Zeeland gedaald van de tweede naar de negentiende plaats van de westerse wereld. In $1984 \mathrm{kwam}$ er een socialistische regering aan de macht die hierin verandering begon te brengen. Het was vooral de Minister van Financiën, Roger Douglas, die de eerste lijnen uitzette voor én van de meest omvangrijke herstructureringsprogramma's van de westerse wereld. Naast het klassieke recept van verlaging van de overheidsuitgaven, verlaging van de belastingen en beperking van de inflatie, omvatte het programma bovenal een enorm dereguleringsprogramma. De onderdelen van dit programma hadden betrekking op de landbouw, de financiële sector,

${ }^{5}$ Zie hierover ook Dewatripont en Roland (1992). 
de overheid, de gezondheidszorg, het onderwijs en de arbeidsmarkt. ${ }^{6}$ Door de aanvankelijke starheid van de Nieuw-Zeelandse economie had het nieuwe economische beleid pas na 4 jaar echt effect. Vanaf begin jaren negentig bevindt de inflatie zich echter op een niveau van 1 à $2 \%$, is de economische groei terug, bevindt deze zich op een niveau van $4 \%$ en daalt tevens de werkloosheid. Bovendien zijn de groeiverwachtingen voor de komende jaren goed. In zijn recente boek Unfinished Business kijkt Douglas terug op het structurele dereguleringsprogramma en formuleert een aantal randvoorwaarden voor succesvolle structurele hervormingen. Douglas merkt hierover onder andere op: "Let the dog see the rabbit. People cannot cooperate with the reform process unless they know where you are going. Where feasible, spell out your objectives and intentions in advance. If programmes are to be implemented in stages, start by publishing the timetable. Businesses and professional analysts understand the importance of quality in decision making and the benefits of mediumterm policies. In time, their increasing goodwill towards the programmes becomes a major factor in creating a favourable climate of public opinion".

Regeringen die de blokkades van belangengroepen in hun economieën aanpakken, hebben daarvoor niet alleen een flinke dosis politieke moed nodig, maar ook informatie, zowel richting politiek als richting publieke opinie. In de woorden van Olson (1982): "Information and calculation about a collective good is often itself a collective good". Goede informatie over structurele veranderingen en vooral over deregulering bestaat uit kwantificering van de kosten en opbrengsten van overheidsingrijpen, en legt nadruk op de lange termijn effecten van overheidsbeleid. Bovendien is deze informatievoorziening onafhankelijk van de politiek.

${ }^{6} \mathrm{Zie}$ voor een beschrijving van de inhoud van het dereguleringsprogramma in Nieuw-Zeeland ook Eichholtz en Koedijk (1993a). 
Bovenstaande elementen hebben Eichholtz en ondergetekende in december 1993 gebracht tot het formuleren van een voorstel voor het oprichten van een Rekenkamer voor Deregulering in het tijdschrift Economisch Statistische Berichten. In het kader van deze rede ga ik kort in op dit voorstel en op twee belangrijke elementen eruit, omdat ze naar mijn mening duidelijk illustreren hoe het streven naar een sterkere overheid, die sneller kosten en baten van de eigen acties durft voor te rekenen, zou kunnen worden ondersteund en daarmee zou een verbeterde groeidynamiek van de economie bereikt kunnen worden.

\section{Een Rekenkamer voor Deregulering}

Een Rekenkamer voor Deregulering zou een belangrijke instelling kunnen zijn om politici en publieke opinie te motiveren om de verstarring van de economie aan te pakken. Een dergelijk instituut kan tevens helpen bij het op gang brengen van een systematische analyse van de effecten van overheidsregulering. In het voorstel van Eichholtz en mijzelf gaan we er vanuit dat het instituut politiek onafhankelijk is en naar eigen inzicht in contact kan treden met de publieke opinie en de politiek. Als opdracht kan aan het instituut worden meegegeven om via analyses en eventueel vergelijkende landenstudies rigiditeiten in de Nederlandse economie in kaart te brengen, de effecten ervan zoveel mogelijk te kwantificeren en waar mogelijk alternatieven aan te dragen. De lijst van mogelijke aandachtsgebieden is lang en zou bijvoorbeeld het effect van regulering en subsidiëring op het gebied van volkshuisvesting, gezondheidszorg, onderwijs, landbouw, sociale zekerheid, telecommunicatie en vervoer kunnen omvatten. Het instituut dient relatief klein van omvang te zijn en zou in eerste instantie opgericht kunnen worden voor een periode van 10 jaar, waama geëvalueerd zou kunnen worden of het instituut al dan niet opgeheven moet worden. Dit zou voorkomen dat het via competentiekwesties met andere adviserende instellingen van de overheid het eigen voortbestaan probeert veilig te stellen en dat de Rekenkamer voor Deregulering een blok aan het been van deregulering wordt. 
Het oprichten van een Rekenkamer voor Deregulering langs de hierboven geschetste lijnen zou een belangrijke aanvulling kunnen zijn op het reeds bestaande werk van de Algemene Rekenkamer. ${ }^{7}$ Deze instelling verricht al bijna 180 jaar onderzoek naar de ontvangsten en uitgaven van het Rijk. Naast rechtmatigheidscontrole, dus de controle of een bepaalde uitgave wel gedaan had mogen worden gegeven het wettelijk kader, verricht de Algemene Rekenkamer ook doelmatigheids- of efficiency-controles van de Rijksuitgaven en -inkomsten. Bekende voorbeelden op dit gebied uit het niet zo verre verleden zijn de onderzoeken naar de omvangrijke kostenoverschrijdingen bij de bouw van twee onderzeeërs van de marine en bij de bouw van de Oosterscheldedam, het onderzoek naar het beleid van de Rijksmusea, en het onderzoek naar de bestrijding van langdurige werkloosheid door de arbeidsbureaus.

Het merendeel van de taken van de Algemene Rekenkamer bestaat echter uit rechtmatigheidscontroles. Dit hangt nauw samen met het feit dat de overheid in het verleden slechts schoorvoetend akkoord ging met het uitbreiden van de doelmatigheidscontrole. Een Rekenkamer voor Deregulering zou een belangrijke versterking kunnen zijn van de doelmatigheidscontrole. Het takenpakket van de Rekenkamer voor Deregulering zou echter belangrijk verder kunnen gaan dan alleen het functioneren van het Rijk en zou ook analyses kunnen omvatten van andere sectoren van de economie. Een belangrijk verschil zou voorts kunnen zijn dat de Rekenkamer voor Deregulering wat betreft haar werkzaamheden dichter bij de politieke besluitvorming zou staan, en een grotere vrijheid zou hebben om alternatieven aan te dragen voor bestaande situaties.

Belangrijk om te vermelden is dat onderdelen van bovenstaand voorstel al beleidspraktijk zijn in andere landen en daar in sommige gevallen al succesvol zijn. Bolhuis en Gradus (1994) beschrijven in een

${ }^{7}$ Zie voor een uitgebreide beschrijving van het werk van de Algemene Rekenkamer, Stevers (1979) en Magry, Van Heukelom, en Linders (1989). 
recent artikel de ervaringen met deregulering in Duitsland, Japan het Verenigd Koninkrijk en Nieuw-Zeeland. Over Japan merken zij op: "Sinds het aantreden van de regering Hosokawa in augustus 1993 staat deregulering hoog op de politieke agenda. Begin september 1993 werd de Economic Reform Research Council (ERRC) in het leven geroepen en in november werd een interimrapportage met de contouren waarlangs de deregulering vorm zou moeten krijgen, afgerond", en bovendien: "In de interimrapportage wordt voorgesteld een aantal task forces onder leiding van de Minister-President te benoemen, die meteen een aanvang maken met het proces van deregulering. Daarnaast krijgen $z \mathrm{ij}$ in het fiscale jaar 1994 de opdracht te komen met plannen, die betrekking hebben op een periode van vijf jaar. Bovendien adviseert de ERRC om een onafhankelijk lichaam - rechtstreeks rapporterende aan de Minister President - in het leven te roepen, dat de taak krijgt erop toe te zien dat de deregulering ook daadwerkelijk wordt geëffectueerd". Ook in Mexico is een sterk dereguleringsprogramma doorgevoerd. Van Wijnbergen (1994) heeft recentelijk de situatie in Mexico als volgt beschreven: "In Mexico werd dit probleem enige jaren geleden aangepakt door een staatssecretaris voor administratieve vereenvoudiging en deregulering aan te stellen, met directe toegang tot de president en de plicht binnen een bepaalde periode op klachten over 'red tape' te reageren met expliciete maatregelen. Deze positie is uiteindelijk uitgebouwd tot een presidentiële commissie voor mededingingsbeleid naar Amerikaans model".

In het voorstel voor de Rekenkamer voor Deregulering zijn vooral de politieke onafhankelijkheid en de beleidsvoorbereiding van groot belang. Beide onderdelen wil ik hier benadrukken.

\section{Politieke onafhankelijkheid}

Goede en relevante informatie over de korte en lange termijn effecten van (de)regulering zijn een noodzakelijke voorwaarde voor politici om bij economische hervormingen voldoende steun te kunnen vinden bij de publieke opinie en daarmee blokkades van deelbelangen te door- 
breken. De kwaliteit van de informatievoorziening staat of valt met de betrouwbaarheid, en daarmee met de onafhankelijkheid van de politiek. De resultaten die geboekt zijn in de politiek-economische literatuur geven aan dat het beoordelen van regulering of het gebrek daaraan moet gebeuren door een instantie die politiek onafhankelijk is. Belangengroepen zullen immers politieke druk uitoefenen tegen elke mogelijke aantasting van hun gevestigde belang. Politieke onafhankelijkheid zal het mogelijk maken hieraan te ontsnappen.

Het belang van politieke onafhankelijkheid bij de beoordeling van overheidsregulering of juist het ontbreken van overheidsregulering wordt goed geillustreerd door een vergelijking tussen de discussie over de wenselijkheid van overheidsregulering in de jaren negentig met de discussie over inflatie in de jaren zeventig. $\mathrm{Na}$ de oliecrisis in 1973 nam wereldwijd de inflatie toe. Eind jaren zeventig bedroeg de inflatie in de meeste westerse landen meer dan $10 \%$ op jaarbasis. In het begin van de jaren tachtig werd er wereldwijd een belangrijk deflatieproces doorgevoerd met als gevolg dat de inflatie snel daalde naar 2 à $3 \%$, maar waarbij tevens op korte termijn belangrijke produktieverliezen werden geleden. De ervaringen in de jaren zeventig en tachtig leerden dat inflatie alleen kan worden beheerst als de groei van de geldhoeveelheid gecontroleerd wordt. Dit bleek het best te lukken indien de centrale bank, de toezichthouder op de ontwikkeling van de geldhoeveelheid, zoveel mogelijk los van de politiek kan opereren. Een onafhankelijke centrale bank is immers het best bestand tegen de druk van belangengroeperingen die de economie via monetaire middelen uit het economische dal willen stimuleren. In de economische literatuur wordt het verband tussen politieke onafhankelijkheid en lage inflatie ondersteund door recent werk van Alesina en Summers (1993). Zij laten zien dat doorgaans geldt: hoe onafhankelijker de centrale bank, hoe lager de inflatie. Bovendien lijkt het erop dat een onafhankelijke centrale bank ook een bijdrage levert aan een stabiel economisch klimaat met een hogere economische groei als gevolg. Deze resultaten hebben ertoe geleid dat zelfs een land als Frankrijk zijn centrale bank minder afhankelijk van de politiek maakt. De con- 
clusies met betrekking tot het toezicht op de ontwikkeling van de inflatie is in belangrijke mate ook van toepassing op het toezicht op de regulerings-ontwikkeling.

Ook in historisch opzicht is het verschil in ontwikkeling tussen het denken over inflatie en het denken over regulering opvallend. Dit wordt des te duidelijker indien we ons realiseren dat de natuurlijke toezichthouders op beide gebieden, namelijk De Nederlandsche Bank en de Algemene Rekenkamer, allebei rond 1814 ten tijde van de regering van Koning Willem $I$ ingesteld zijn. Op het monetaire vlak zijn we inmiddels tot het inzicht gekomen dat de maatschappij op lange termijn erbij gebaat is dat De Nederlandsche Bank zoveel mogelijk onafhankelijk is, dat zij een volwaardige taak op monetair terrein heeft, en dat de President van De Nederlandsche Bank zich op ieder gewenst moment tot de publieke opinie kan richten over financieel-economische zaken. Op regulerings- en dereguleringsvlak is het denken nog niet zover en vervult de President van de Algemene Rekenkamer nog geen vergelijkbare rol als die de President van De Nederlandsche Bank op monetair gebied heeft.

\section{Beleidsvoorbereiding}

Voor een goede analyse van starheden in de economie is een goede beleidsondersteuning en beleidsvoorbereiding nodig. Traditioneel heeft de beleidsvoorbereiding in Nederland een hoog macro- en modellengehalte. Bekend zijn in dit opzicht de econometrische modellen van het Centraal Planbureau. Voor analyses van de economische ontwikkeling over een reeks van jaren en de effecten van teveel of te weinig regulering zijn deze modellen onvoldoende uitgerust. $\mathrm{Bij}$ de ontwikkeling van de huidige klasse van jaargangmodellen van het Centraal Planbureau vormt de ontwikkeling van de loonvoet per werknemer het centrale element. Alles dat in deze modellen zorgt voor een gematigde ontwikkeling van de loonkosten, is goed voor de werkgelegenheid. Loonkostenmatiging vormt dan ook het centrale thema in de beleidsaanbevelingen van het Centraal Planbureau. Allerlei andere elementen 
die voor de lange-termijn ontwikkeling van een economie van belang zijn, zoals de mate van regulering, de mate van subsidiëring en de marginale belastingdruk, zijn niet of onvoldoende in deze modellen verwerkt en krijgen dus onvoldoende aandacht in de beleidsaanbevelingen. Voor een grondige analyse van deregulering zijn dan ook meer micro-economische analyses gewenst. De implicaties van een verschuiving van macro naar micro voor het analyseren van structurele rigiditeiten zijn recent onder andere door Kremers (1991) onder de aandacht gebracht. Over de mogelijkheden om met behulp van macro-modellen structurele rigiditeiten te analyseren merkt hij op: "De grote verscheidenheid aan beleidsinstrumenten die op micro-terrein van belang zijn, maakt het moeilijk - zo niet onmogelijk - om ze in éen econometrisch model te vatten". Bij het analyseren van structurele rigiditeiten in de economie dienen we het veeleer te hebben van (partiële) micro-analyses die per sector aangeven wat de belangrijkste knelpunten en kosten zijn en wat de eventuele oplossing hiervoor kan zijn. De micro-analyses kunnen zowel kwalitatief als kwantitatief van aard zijn. In het buitenland worden de voorbeelden van kwantitatieve micro-analyses van overheidsbeleid en deregulering talrijker. Daarbij wordt dan aangegeven wat de welvaartswinst is voor consumenten, producenten en de samenleving als geheel. Recentelijk heeft Winston (1993) in de Journal of Economic Literature de effecten van verschillende dereguleringsprogramma's in de jaren zeventig en tachtig voor consumenten en producenten in de Verenigde Staten gekwantificeerd. De dereguleringsprogramma's hadden onder andere betrekking op de luchtvaartindustrie, de spoorwegen, het vrachtvervoer, de telecommunicatie, de kabeltelevisie en de aandelenhandel. Op grond van conservatieve schattingen raamt Winston de gezamenlijke welvaartswinst op 36 tot 46 miljard dollar (70 tot 90 miljard gulden) per jaar. Dit is ongeveer 7 tot $9 \%$ van het nationale inkomen van de Verenigde Staten.

Het kwantificeren van de opbrengsten van deregulering maakt het eenvoudiger om aan het publiek duidelijk te maken wat de winst van deregulering voor de samenleving als geheel is. Dit wil echter niet 
zeggen dat micro-analyses voldoende zijn om de effecten van regulering volledig in kaart te brengen. De effecten van deregulering op de lange termijn kunnen noch door macro-economische, noch door micro-economische analyses volledig worden becijferd. Voor beide vormen van aanpak, macro en micro, geldt dat het ruwe benaderingen van de werkelijkheid zijn die in sommige gevallen niet of onvoldoende rekening houden met de economische dynamiek. In die gevallen kan een blik over de grens uitkomst bieden. In dergelijke studies kan worden geanalyseerd in hoeverre deregulering succesvol is geweest, wat de belangrijkste voordelen en nadelen over een reeks van jaren zijn geweest en wat de mogelijkheden voor Nederland zijn op dit gebied. Opvallend aan discussies over het economisch beleid in $\mathrm{Ne}$ derland is de sterke gerichtheid op het binnenland. Slechts in enkele gevallen worden Nederlandse ontwikkelingen in een breder kader geplaatst door ze te vergelijken met ontwikkelingen in andere landen. Een relevant voorbeeld met betrekking tot deregulering is de markt voor telecommunicatie. In Nederland woedt momenteel een discussie over de toekomstige vormgeving van de markt voor telecommunicatie. Naast de PTT dient zich een aantal potentiële toetreders als de Spoorwegen en de banken aan. Inzet is een belangrijke marktpositie op de toekomstige markt voor telecommunicatie. Voor de overheid lijkt hier een belangrijke taak weggelegd. Alvorens echter als overheid een definitieve keuze te doen in een specifieke richting lijkt het overwegen waard om na te gaan hoe andere overheden de afweging hebben gemaakt. Een relevant voorbeeld is weer Nieuw-Zeeland, waar de afgelopen jaren de markt voor telecommunicatie met succes gedereguleerd is. Als gevolg van de deregulering van de telecommunicatie-industrie in dit land daalden de prijzen met $21 \%$ in het eerste jaar en nam de wachttijd voor een telefoonaansluiting af van 6 weken tot minder dan 2 dagen. Vooral dit laatste, de verbeterde kwaliteit van de dienstverlening, zou met micro-analyses alleen niet te voorspellen zijn en wordt na het bestuderen van Nieuw-Zeelandse ervaringen wel duidelijk. De mogelijkheden om van andere landen te leren beperken zich niet tot telecommunicatie, maar bestrijken een groot aantal sectoren. De moeite waard zijn bijvoorbeeld de experimenten met het intro- 
duceren van een grotere dynamiek in het overheidsmanagement in Nieuw-Zeeland. In dit land is vijf jaar geleden bij de overheid een 'corporization process' doorgevoerd. Als onderdeel van dit proces zijn de mogelijkheden om binnen de overheid te belonen naar prestatie sterk verruimd. Top-ambtenaren sluiten aan het begin van een kabinetsperiode met de minister een contract af over de te behalen resultaten en worden hierop afgerekend. Deze vernieuwing van het overheidsmanagement heeft inmiddels zijn vruchten afgeworpen: in een recent overzicht van World Economic Forum met betrekking tot de kwaliteit van de overheid bekleedde Nieuw-Zeeland de eerste plaats van in totaal 22 besproken westerse landen.

Echt vernieuwend is voorts de verandering van de verslaggeving van de overheid. De Nieuw-Zeelandse overheid publiceert sinds 1991 jaarlijks een balans, een staat van herkomst en besteding van de middelen, en een winst- en verliesrekening, net zoals ieder beursgenoteerd bedrijf dat doet. Hoewel dit op korte termijn praktische problemen met zich meebrengt, zoals het waarderen van bijvoorbeeld wegen en openbare diensten, geeft een dergelijke verslaggeving een veel eerlijker en rationeler beeld voor huidige en toekomstige generaties van de effecten van overheidsbeleid op de nationale economie.

Niet alleen met micro- of macro-analyses of met vergelijkende studies valt iets te zeggen over te veel of te weinig overheidsbeleid en de kosten die hieraan verbonden zijn. Het instrumentarium van de financierings- en beleggingsleer kan hierbij ook behulpzaam zijn en aldus een bijdrage leveren aan een betere verantwoording. Hieronder werk ik dit in de vorm van een voorbeeld verder uit.

\section{Pensioenfondsbeheer in relatie tot de financierings- en beleg- gingsleer}

In Nederland bestaat er naar mijn stellige overtuiging te veel onnodige mist op het gebied van de performance-evaluatie bij pensioenfondsen. Ik wil in de rest van dit betoog laten zien dat een sterkere rol van de 
overheid en/of Verzekeringskamer op dit gebied in combinatie met de theoretische inzichten uit de financierings- en beleggingsleer kan leiden tot een grotere openheid over het beleid van pensioenfondsen, op termijn tot betere beleggingsresultaten en mogelijk tot lagere pensioenpremies.

De wetenschappelijke analyse van rendementen in de financieringsliteratuur kreeg in 1952 een impuls door het belangrijke artikel Portfolio Selection van de hand van Markowitz (1952) in de Journal of Finan$c e$. In dit artikel toonde Markowitz aan dat risico en rendement verschillende zijden van dezelfde medaille zijn en dus dat een hoger rendement alleen te realiseren valt als je een hoger risico accepteert. Misschien nog belangrijker was dat hij aantoonde hoe je het risico van beleggingen kan verlagen bij gelijkblijvend rendement door diversificatie: het spreiden van de beleggingsportefeuille over beleggingen die niet met elkaar in tandem bewegen. Recentelijk vatte Bernstein (1992) de basisideeën achter de portefeuilletheorie kernachtig samen: "It boils down to nothing more than a formal confirmation of two old rules for investing: Nothing ventured, nothing gained. Don't put all your eggs in one basket. Markowitz defined these familiar rules with scientific precision, using mathematics to solve the puzzle of the investor's trade-off. His analysis shows precisely how investors can combine their hopes of realizing the largest possible gain with exposure to the least possible risk".

Markowitz' portefeuilletheorie werd in 1964-1965 van een praktisch handvat voorzien door Sharpe en Lintner die aantoonden dat het risico van een belegging afhangt van de mate waarin de belegging meefluctueert met de bewegingen in de marktportefeuille. Op basis van het werk van Sharpe (1964) en Lintner (1965) werd het mogelijk om voor individuele beleggingen de risico-rendementsafruil te kwantificeren. Hiermee was het Capital Asset Pricing Model (CAPM) geboren. De latere implementatie van de portefeuilletheorie en het CAPM in de financiële praktijk werd mogelijk door de ruime beschikbaarheid van financiële gegevens en de razendsnelle ontwikkeling van de computer- 
technologie. Daarmee werd het mogelijk om de ontwikkelde theorieën direct te toetsen aan de empirische praktijk en indien nodig bij te stellen. Uit deze interactie van financiële theorie en empirie is in de afgelopen veertig jaar een aantal praktische instrumenten en technieken ontstaan die van groot nut zijn bij het beleggen van vermogen. Hiermee zijn we aangeland bij de hoofdtaak van de pensioenfondsen en daarmee bij het onderwerp van de rest van deze oratie.

De pensioenfondsen in Nederland behoren tot de institutionele beleggers en worden traditioneel onderverdeeld in ondernemings-, bedrijfsen beroepspensioenfondsen. ${ }^{8}$ In totaal zijn er circa 1200 pensioenfondsen in Nederland. Eind 1992 bedroeg het totaal belegd vermogen van deze fondsen circa 440 miljard gulden. Daaronder neemt het Algemeen Burgerlijk Pensioenfonds (ABP) als ambtenarenpensioenfonds met een belegd vermogen van 173 miljard gulden een belangrijke plaats in. Wanneer we het totale vermogen van 440 miljard gulden delen door het aantal inwoners in Nederland resulteert een bedrag van 31.500 gulden aan belegd pensioenvermogen. Per hoofd van de bevolking bezet Nederland daarmee de eerste plaats, vóór de Verenigde Staten, Japan en het Verenigd Koninkrijk. De inkomsten uit de beleggingen van de pensioenfondsen moeten samen met de pensioenpremies en andere ontvangsten voor een vermogen zorgen dat groot genoeg is om de toegezegde pensioenuitkeringen te kunnen betalen. In de meeste gevallen is sprake van een zogenaamde eindloonregeling op basis waarvan het bruto-pensioen de AOW-uitkering en/of eventuele andere uitkeringen aanvult tot maximaal ongeveer zeventig procent van het laatst genoten bruto loon of salaris. Om deze pensioenaanspraken nu en in de toekomst te kunnen honoreren is het van belang dat pensioenfondsen een voldoende rendement realiseren. Hiertoe beleggen pensioenfondsen in Nederland traditioneel een substantieel deel van hun vermogen in vastrentende waarden als obligaties en onderhandse leningen. In 1980 belegde het gemiddelde Neder-

${ }^{8}$ Zie ook van Loo (1984). 
landse pensioenfonds circa $82 \%$ van het totale vermogen in vastrentende waarden en bleef er dus slechts $18 \%$ over om te beleggen in zakelijke waarden als aandelen en onroerend goed. Sinds 1980 zijn pensioenfondsen een dynamischer koers gaan varen en is het percentage aandelen en onroerend goed systematisch uitgebreid. In 1992 bedroeg het percentage aandelen en onroerend goed reeds meer dan $27 \%$ van de gezamenlijke beleggingsportefeuille. Op deze manier hopen pensioenfondsen enerzijds te profiteren van het hogere rendement van aandelen en onroerend goed op lange termijn en anderzijds van een verlaging van het portefeuillerisico door een sterkere diversificatie."

Door het toegenomen belang van de beleggingsopbrengsten en door de grotere spreiding over verschillende beleggingscategorieën, wordt het voor pensioenfondsbestuurders en pensioengerechtigden belangrijk om de resultaten van het beleggingsbeleid door middel van performance-meting te kunnen volgen. Performance-meting bij pensioenfondsen kan verschillende doelen dienen. Intern kan performance-meting worden gebruikt als ondersteuning bij de beleidsvoorbereiding en als onderdeel van het verantwoordingsproces. Extern kan performancemeting worden gebruikt om het beleggingsbeleid van verschillende pensioenfondsen met elkaar te kunnen vergelijken. Performancemeting over een reeks van jaren kan bijvoorbeeld aan het licht brengen of het ABP het systematisch beter of slechter doet dan het Shellpensioenfonds of het pensioenfonds PGGM. Indien uit de performance-meting naar voren komt dat één van de pensioenfondsen systematisch een slechter rendement realiseert dan de andere pensioenfondsen en/of voortdurend achterblijft bij de marktontwikkeling, kan het beleggingsbeleid van de desbetreffende instelling aan een nader onderzoek onderworpen worden en, indien nodig, aangepast worden. Internationaal is al de nodige ervaring opgedaan met performancemeting bij pensioenfondsen. Met name in de Verenigde Staten bestaat

${ }^{9}$ Zie ook Wolff (1989). 
al meer dan 30 jaar een gevestigde traditie in het meten en evalueren van de rendementen van pensioenfondsen. Niet zelden komen in dit land bij evaluaties van pensioenfondsrendementen opvallende zaken naar boven. In een recent overzichtsartikel hebben Lakonishok, Schleifer en Vishny (1992) het beleggingsbeleid van 769 Amerikaanse pensioenfondsen tussen 1983 en 1989 geanalyseerd. Uit het onderzoek kwam naar voren dat een belangrijk deel van de pensioenfondsen op hun aandelenportefeuille systematisch 1.5 tot $2.5 \%$ minder rendement realiseerde dan de Amerikaanse Standard \& Poors aandelenindex!

Een eerste vereiste voor een consistente performance-meting is eenduidigheid over de waarderingsgrondslagen. Indien het ene fonds aandelen tegen beurswaarde waardeert, terwijl het volgende fonds aandelen tegen verwervingsprijs waardeert, is er weinig reden voor een consistente performance-meting en -vergelijking tussen de pensioenfondsen. Helaas ondervindt de geïnteresseerde pensioengerechtigde in Nederland weinig steun van de wetgever en de Verzekeringskamer, die belast is met het toezicht op de pensioenfondsen. In de zogenaamde Pensioen- en Spaarfondsenwet is geen stelsel van formele en materiële regels opgenomen, waaraan de verslaggeving van pensioenfondsen zou moeten voldoen. Voor de waardering van activa en passiva en de bepaling van het resultaat of rendement ontbreken dwingende voorschriften. Gevolg is dat de jaarlijks gerapporteerde rendementen in grote mate beïnvloed kunnen worden door gehanteerde waarderingsgrondslagen. Uit verschillende publikaties ${ }^{\text {in }}$ en uit eigen onderzoek blijkt dat in Nederland een grote verscheidenheid bestaat aan waarderingsgrondslagen. Onderzoek door de toenmalige Bank Mees \& Hope uit 1984 laat zien dat obligaties door ruim 40\% van de fondsen à pari wordt gewaardeerd, door ruim $30 \%$ tegen beurswaarde en door bijna $30 \%$ tegen historische verwervingsprijs. De waardering van onderhandse leningen en hypothecaire leningen vindt door ongeveer $75 \%$ van de fondsen tegen pari plaats en voor de rest

${ }^{10}$ Zie Klaassen en De With (1984) en Bank Mees \& Hope (1984). 
doorgaans tegen historische verwervingsprijs. Bank Mees \& Hope laat voorts zien dat aandelen door 80 à $85 \%$ van de fondsen tegen beurswaarde en voor het overige meestal tegen historische verwervingsprijs of het minimum van historische verwervingsprijs en beurswaarde worden gewaardeerd. Direct onroerend goed wordt door ruim de helft van de fondsen tegen marktwaarde c.q. meest recente marktwaarde gewaardeerd en in andere gevallen tegen historische verwervingsprijs. Indirect onroerend goed tegen beurswaarde, historische verwervingsprijs of het minimum van historische verwervingsprijs en beurswaarde. Gevolg van deze verscheidenheid aan balans- en resultaatwaardering is dat moeilijk uit de jaarverslagen is af te leiden hoe goed of slecht het beleid van het pensioenfonds in het afgelopen jaar is geweest en helemaal niet of dat beleid verbeterd zou kunnen worden. Voor pensioengerechtigden en de pensioenfondsbestuurders is dit een weinig gelukkige situatie. Iedereen wil aan het eind van het jaar weten hoeveel rente hij of zij ontvangen heeft op de spaarrekening. Ook wil iedereen het rendement van zijn aandelenbelegging weten en liefst ook of dit nog hoger had kunnen zijn. Zo heeft ook iedere pensioengerechtigde en pensioenfondsbestuurder recht op inzicht in het pensioenrendement. Gelukkig beginnen een aantal pensioenfondsen de noodzaak van performancemeting en evaluaties te onderkennen en beginnen er steeds meer ranglijstjes met pensioenfondsrendementen te verschijnen. Het ABP heeft de afgelopen twee jaar op dit gebied een voortrekkersrol vervuld. Recentelijk publiceerde het ABP een lijst van resultaten van 13 pensioenfondsen tussen 1989 en 1992 zoals weergegeven in tabel 1 . In deze tabel zijn zowel het rendement op aandelen, op onroerend goed (O.G. in de tabel), op obligaties als ook het totaal rendement weergegeven.

Het ABP stelt in de publikatie dat bij de interpretatie van de resultaten de nodige voorzichtigheid betracht moet worden: "Met nadruk zij gesteld dat ondanks het feit dat het getallenmateriaal zoveel mogelijk tot vergelijkbare grootheden herleid is, er geen absolute waarde aan mag worden toegekend", en "De getallen moeten dan ook meer als richtingbepalend worden geïnterpreteerd". Desondanks komen uit de 
gepresenteerde tabel opvallende verschillen naar voren. Het verschil wordt des te groter indien ze worden vermenigvuldigd met de omvang van het belegd vermogen. Opvallend is vooral het verschil in spreiding tussen enerzijds het rendement op vastrentende waarden als obligaties en hypothecaire leningen en anderzijds het rendement op aandelen en onroerend goed. Bij de vastrentende waarden bedraagt de spreiding tussen hoogste en laagste rendement slechts $1.8 \%$, terwijl dit bij aandelen en onroerend goed respectievelijk $11.8 \%$ en $6.4 \%$ bedraagt.

Het is belangrijk om hier aan te stippen dat de gepresenteerde tabel slechts een eerste stap kan zijn op weg naar een evenwichtige evaluatie van pensioenrendementen. Hierboven heb ik immers uiteengezet dat één van de fundamentele inzichten van de financierings- en beleggingsleer is dat risico en rendement onlosmakelijk met elkaar verbonden zijn. Voor een volledige evaluatie van de pensioenrendementen zou men dan ook moeten corrigeren voor het risicoprofiel van het pensioenfonds. Slechts dan is een werkelijk evenwichtige vergelijking mogelijk. Belangrijk om te realiseren is dat de financierings- en beleggingsleer al meer dan 30 jaar over het instrumentarium beschikt om dit op correcte wijze te kunnen doen en dat er in landen als de VS al evenlang expertise bestaat juist op dit gebied.

Hoe een dergelijke evenwichtige evaluatie in Nederland uit zou kunnen pakken, kunnen we illustreren aan de hand van de resultaten van beleggingsfondsen. Door de grotere openheid omtrent de resultaten van beleggingsfondsen is het kwantificeren en evalueren van de resultaten van deze instellingen eenvoudiger. Sinds enkele jaren publiceren bladen als Beleggers Belangen en Elsevier dan ook jaarlijks een ranglijst met de beste beleggingsfondsen. Vanzelfsprekend is hierbij van belang welke maatstaf gehanteerd wordt om risico en rendement mee te evalueren. In de financierings- en beleggingsliteratuur zijn met name de Treynor-, Jensen- en Sharpe- maatstaf bekend. Ieder van deze maatstaven heeft voor- en nadelen. Voor een evenwichtige en robuuste vergelijking van beleggingsrendementen dienen daarom 


\section{Tabel 1: Pensioenfondsrendementen 1989 - 1992}

\begin{tabular}{|l|rrrr|}
\hline & $\begin{array}{r}\text { Aan- } \\
\text { delen }\end{array}$ & O.G. & $\begin{array}{c}\text { Obli- } \\
\text { gaties }\end{array}$ & Totaal \\
\hline Spoorwegen & 7.5 & 5.1 & 7.8 & 7.6 \\
ABP & 5.3 & 4.4 & 7.9 & 7.5 \\
Metaalnijverheid & -0.2 & 6.7 & 8.4 & 7.5 \\
DSM & 5.3 & 6.8 & 8.1 & 7.4 \\
Unilever & 6.1 & 7.8 & 8.1 & 7.3 \\
Philips A & 7.2 & 4.2 & 8.2 & 7.2 \\
AKZO & 4.0 & 6.9 & 8.1 & 6.9 \\
Philips B & 6.7 & 4.6 & 7.3 & 6.7 \\
PGGM & 3.0 & 4.9 & 8.2 & 6.6 \\
Hoogovens & 4.0 & 3.4 & 7.4 & 6.1 \\
KLM & -4.3 & 4.4 & 7.9 & 6.0 \\
Metaalindustrie & -3.8 & 3.2 & 8.4 & 5.2 \\
Shell & 0.2 & 1.4 & 9.1 & 3.5 \\
\hline
\end{tabular}

Bron: ABP wereld, oktober 1993.

meerdere criteria gebruikt te worden. Recent heeft een onderzoeksgroep binnen het Limburg Institute of Financial Economics (LIFE) bestaande uit Arjan van Bussel, Jan-Willem Goslings, Peter Schotman, Bert van Tuel en ondergetekende uitvoerig onderzoek gedaan naar de verschillende maatstaven" voor beleggingsrendement. Op basis van dit onderzoek is een robuuste index voor beleggingsrendementen van aandelenfondsen ontwikkeld. Deze index, die kortweg aangeduid zal worden als de LIFE-index, is een maatstaf voor de mate waarin beleggingsinstelingen in staat zijn om over langere perioden significant buitengewoon rendement te realiseren en voor de mate waarin beleggingsinstellingen in staat zijn om gedurende langere tijd de marktontwikkeling op verschillende aandelenbeurzen te volgen. In tabel 2 zijn

"Zie ook Lehmann en Modest (1987) en Glosten en Jagannathan (1994). 
deze maatstaven achtereenvolgens aangeduid met $\alpha$ en $\mathrm{R}^{2}$. Onder de $\alpha$ staan de $t$-waarden voor statistische signifcantie. De LIFE-index is een gewogen gemiddelde van deze twee maatstaven $\left(\alpha\right.$ en $\mathrm{R}^{2}$ ). In het kader van dit betoog ga ik niet verder in op de technische kanten van de constructie van de LIFE-index maar verwijs hiervoor naar de publikatie "Een LIFE-Index voor Beleggingsrendement", die in voorbereiding is. Wel wil ik hier alvast laten zien hoe zo'n robuuste maatstaf voor beleggingsrendementen uitpakt voor aandelenfondsen in Nederland. In de onderstaande tabel 2 treft $u$ de LIFE-index aan voor 33 beleggingsinstellingen over de periode 1988-1993. Op basis van de LIFE-index is het mogelijk om beleggingsinstellingen als het ware rapportcijfers te geven. Een kort voorbeeld kan de LIFE-index verduidelijken. Het ING Bank Dutch Fund realiseerde over deze periode weliswaar een hoger buitengewoon rendement dan bijvoorbeeld Robeco, maar was daarentegen ook veel minder dan Robeco in staat om ontwikkelingen op de verschillende beurzen te volgen. Het ING Bank Dutch Fund eindigt hierdoor lager op de LIFE-index dan Robeco. Ter vergelijking is in onderstaande tabel naast de ranglijst op basis van de LIFE-index de meest recente ranglijst van Elsevier opgenomen. Uit de vergelijking komen opvallende verschillen naar voren. De verschillen worden voomamelijk veroorzaakt doordat de LIFE-index minder belang hecht aan incidentele hoge rendementen op basis van zeer specifieke en risicovolle portefeuillesamenstellingen. De fondsen die op de LIFE-index hoog scoren, zijn die fondsen waar een belegger in het algemeen niet snel voor verrassingen komt te staan. 
Tabel 2: LIFE-index van aandelenfondsen, 1988-1993

\begin{tabular}{|c|c|c|c|c|c|}
\hline & $\alpha$ & $\mathrm{R}_{\text {adj }}^{2}$ & $\begin{array}{l}\text { LIFE } \\
\text { index }\end{array}$ & $\begin{array}{c}\text { LIFE } \\
\text { rang- } \\
\text { lijst }\end{array}$ & $\begin{array}{l}\text { Elsevier } \\
\text { ranglijst }\end{array}$ \\
\hline Robeco & $\begin{array}{c}2.02 \\
(1.42)\end{array}$ & 0.93 & 8.5 & 1 & 12 \\
\hline Rolinco & $\begin{array}{c}2.76 \\
(1.46)\end{array}$ & 0.92 & 8.5 & 1 & 11 \\
\hline $\begin{array}{l}\text { ABN-AMRO } \\
\text { Far East Fund }\end{array}$ & $\begin{array}{l}8.15 \\
(1.71)\end{array}$ & 0.85 & 8.0 & 3 & 15 \\
\hline Colombia Securities & $\begin{array}{c}3.57 \\
(1.18)\end{array}$ & 0.84 & 8.0 & 3 & 14 \\
\hline $\begin{array}{l}\text { ABN-AMRO Europe } \\
\text { Fund }\end{array}$ & $\begin{array}{c}4.39 \\
(1.53)\end{array}$ & 0.82 & 8.0 & 3 & 16 \\
\hline Obam & $\begin{array}{c}6.47 \\
(2.35)\end{array}$ & 0.76 & 8.0 & 3 & 3 \\
\hline $\begin{array}{l}\text { ING Bank Dutch } \\
\text { Fund }\end{array}$ & $\begin{array}{l}9.48 \\
(3.19)\end{array}$ & 0.73 & 8.0 & 3 & 1 \\
\hline $\begin{array}{l}\text { ABN-AMRO Nether- } \\
\text { lands Fund }\end{array}$ & $\begin{array}{l}6.99 \\
(2.42)\end{array}$ & 0.72 & 8.0 & 3 & 2 \\
\hline $\begin{array}{l}\text { ABN-AMRO America } \\
\text { Fund }\end{array}$ & $\begin{array}{c}0.12 \\
(0.04)\end{array}$ & 0.83 & 7.5 & 9 & 9 \\
\hline Trans Europe Fund & $\begin{array}{c}3.53 \\
(1.16)\end{array}$ & 0.79 & 7.5 & 9 & 23 \\
\hline EOE Index Fund & $\begin{array}{c}6.21 \\
(1.83)\end{array}$ & 0.75 & 7.5 & 9 & 6 \\
\hline $\begin{array}{l}\text { ABN-AMRO Aande- } \\
\text { lenfonds }\end{array}$ & $\begin{array}{c}3.37 \\
(1.27)\end{array}$ & 0.75 & 7.5 & 9 & 5 \\
\hline
\end{tabular}




\begin{tabular}{|l|ccccc|}
\hline Holland Pacific Fund & 5.88 & 0.74 & 7.5 & 9 & 18 \\
Esmeralda & $(1.46)$ & & & & \\
Holland Europe Fund & -0.63 & 0.79 & 7.0 & 14 & 26 \\
& $(0.16)$ & & & & \\
Transpacific Fund & 3.65 & 0.76 & 7.0 & 14 & 21 \\
& $(0.95)$ & & & & \\
Aegon Aandelenfonds & -1.34 & 0.75 & 7.0 & 14 & 27 \\
& $(0.22)$ & & & & \\
Asian Tigers Fund & 2.43 & 0.71 & 7.0 & 14 & 10 \\
Holland Fund & $(0.79)$ & & & & \\
Tokyo Pacific & 11.16 & 0.65 & 7.0 & 14 & 4 \\
Holdings & $(1.95)$ & & & & \\
ING Bank Global & 5.32 & 0.65 & 7.0 & 14 & 20 \\
Fund & $(1.61)$ & & & & \\
Equity \& Law & 5.50 & 0.66 & 6.5 & 20 & 22 \\
Aandelen Nederland & $(0.77)$ & & & & \\
Equity \& Law Beheer & 1.18 & 0.66 & 6.5 & 20 & 17 \\
Nederland & $(0.24)$ & & & & \\
Algemeen & -0.77 & 0.66 & 6.5 & 20 & 8 \\
Fondsenbezit & $(0.24)$ & & & & \\
Far East Selection & -0.29 & 0.63 & 6.5 & 20 & 7 \\
Fund & -0.46 & 0.63 & 6.5 & 20 & 25 \\
Europe Growth Fund & $(0.13)$ & & & & \\
& -0.53 & 0.63 & 6.5 & 20 & 19 \\
\hline$(0.10)$ & & & & \\
\hline & -1.10 & 0.63 & 6.5 & 20 & 31 \\
\hline & $(0.24)$ & & & & \\
\hline
\end{tabular}




\begin{tabular}{|l|ccccc|}
\hline Pacific Dimensions & $\begin{array}{c}-4.06 \\
(0.63)\end{array}$ & 0.63 & 6.5 & 20 & 28 \\
Asia Pacific Growth & 2.62 & 0.60 & 6.5 & 20 & 24 \\
Fund & $(0.36)$ & & & & \\
GOYA-Fund & -6.20 & 0.57 & 5.5 & 29 & 29 \\
& $(1.04)$ & & & & \\
Environment Growth & -14.30 & 0.55 & 5.0 & 30 & 34 \\
Fund & $\begin{array}{c}2.67) \\
4.14\end{array}$ & 0.34 & 5.0 & 30 & 13 \\
DP America Growth & $(0.51)$ & & & & \\
Fund & -3.35 & 0.22 & 4.5 & 32 & 32 \\
Intereffect 500 & $(0.28)$ & & & & \\
Groeigarant & -6.09 & 0.11 & 4.0 & 33 & 30 \\
\hline
\end{tabular}

Een dergelijke analyse zou in de toekomst ook mogelijk moeten zijn bij rendementen van pensioenfondsen in Nederland. Binnen het onderzoeksinstituut LIFE wordt hier momenteel aan gewerkt. Vooralsnog zijn de ranglijstjes zoals die door het ABP gepresenteerd worden niet volledige maar zeer waardevolle aanzetten voor het analyseren van pensioenrendementen.

Gezien de financiële belangen en persoonlijke prestiges maken ranglijstjes zoals door het ABP gepresenteerd per definitie veel discussie los. Dit zal met name het geval zijn bij pensioenfondsen die laag op de ranglijst eindigen. Soms is dit terecht, zoals wanneer te weinig rekening wordt gehouden met het specifieke beleggingsbeleid van een pensioenfonds, soms is dit ook volkomen onterecht. Het zou buitengewoon jammer zijn als door de discussie hieromtrent het begrip ranglijst van pensioenrendementen zou verdwijnen. 
Het opstellen van dergelijke ranglijstjes lijkt dan ook niet zozeer een taak van een afzonderlijk pensioenfonds als het ABP, maar veeleer een taak die weggelegd is voor de landelijke overheid of voor de afdeling Onderzoek van de Verzekeringskamer. Door dwingende richtlijnen te maken voor het resultaat en door jaarlijks het rendement van pensioenfondsen te berekenen, te evalueren en te publiceren in de Staatscourant en in de landelijke kranten doet de overheid wat het behoort te doen: $u$, mij en geheel pensioenfondsenland behoeden voor de winterslaap. 


\section{Dankwoord}

\section{Dames en Heren,}

Ik hoop dat ik $u$ heb laten zien hoe spannend en relevant de financiële economie voor het begrijpen van belangrijke hedendaagse problemen kan zijn. In mijn onderwijs en onderzoek wil ik deze lijn voortzetten.

Het is een goede gewoonte om aan het eind van een inaugurele rede een woord van dank uit te spreken. Graag wil ik van de gelegenheid gebruik maken om iedereen die binnen deze faculteit heeft bijgedragen aan mijn benoeming als onderzoekprofilerings-hoogleraar, met als speciale opdracht de financiële economie en econometrie, te bedanken voor het in mij gestelde vertrouwen.

Onderwijs en onderzoek doe je nooit alleen, maar binnen en samen met een team van mensen. Graag wil ik dan ook de leden van de sectie Financiering bedanken voor de stimulerende samenwerking van de afgelopen jaren en bovenal voor de uiterst plezierige en ontspannen sfeer waarin gewerkt wordt. Ik verheug me op de toekomstige samenwerking.

Hooggeleerde Wolff, Beste Christian,

Sprekend over samenwerking wil ik jou in het bijzonder noemen. Jij was het die me in 1990 benaderde met het verzoek om te solliciteren in Maastricht. Op dat moment was dat niet mogelijk omdat ik net besloten had om in Amsterdam te gaan werken. In 1991 raakten we weer in gesprek en besloot ik te solliciteren. In het afgelopen jaar hebben we nauw samengewerkt binnen de sectie en binnen het net opgerichte onderzoeksinstituut Limburg Institute of Financial Economics (LIFE). Jij hebt me geleerd dat vakkennis alleen niet voldoende is voor de invulling van een hoogleraarsplaats maar dat er meer bij komt kijken. Hiervoor wil ik je dankzeggen. 
Zeer geleerde Kool, Beste Clemens,

Ook jou wil ik hier noemen. In achtereenvolgens Rotterdam, Amsterdam en Maastricht werken we al meer dan 10 jaar samen op het gebied van de monetaire economie. Graag wil ik je hiervoor dankzeggen maar bovenal wil ik je bedanken voor de betoonde vriendschap.

\section{Lieve Wilma,}

Meer dan aan alle anderen heb ik deze leuke baan aan jou te danken. Ik ben je hiervoor heel erkentelijk.

En ten slotte Mirjam,

Zij mag niet ontbreken vanwege de nieuwe dimensie die zij door haar zonnige aanwezigheid aan ons leven toevoegt en vanwege de geheel eigen wijze waarop zij sinds haar geboorte 4 maanden geleden invulling geeft aan de titel van dit betoog.

Graag dank ik u allen voor uw zeer gewaardeerde aandacht. 


\section{GERAADPLEEGDE LITERATUUR}

ABP Wereld (1993), oktober.

Alesina, A. en A. Drazen (1991), Why are stabilizations delayed?, American Economic Review, 81, 1170-1188.

Alesina, A. en L. Summers (1993), Central bank independence and macroeconomic performance: some comparative evidence, Journal of Money, Credit and Banking, 25, 151-162.

Andriessen, J.E. en R.F. van Esch (1993), Globalisering: een zekere trend, Discussienota 9301, Ministerie van Economische Zaken.

Ballendux, F.J. (1984), De kip of het ei? Kanttekeningen bij het beleggingsbeleid van pensioenfondsen, in A.C.C. Herst, P.W. Moerland, J. Spronk (red.): Vermogen in Onzekerheid, Kluwer.

Bank Mees \& Hope (1984), Het beleggingsbeleid van institutionele beleggers in jongste verleden en naaste toekomst, Enquête, Amsterdam.

Bartlema, S. (1991), Performancemeting in de praktijk: trust but verify, VBA Journaal, 26-27.

Barro, R. en J.W. Lee (1993), Losers and winners in economic growth, NBER working paper 4341.

Bernstein, P. (1992), Capital ldeas, The Free Press.

Bie, S.E. de en P.J. Rozendal (1993), Het beperkte inzicht in kosten en profijt van de overheid, Economisch Statistische Berichten, 411-413.

Bolhuis, E. en R. Gradus (1994), Deregulering: vier lessen uit het buitenland, te verschijnen in Economisch Statistische Berichten.

Bomhoff, E.J. (1988), Liever een Gouden Handdruk, Contact.

Buchanan, J.M. (1984), Politiek schuldbesef, Rotterdamse Monetaire Studies, nr. 16.

Buchanan, J.M. en G. Tullock (1962), The Calculus of Consent, University of Michigan Press.

Bussel, P.J.M van, J.H.W. Goslings, C.G. Koedijk, P.C. Schotman, H.M. van Tuel (1994), De LIFE-index van beleggingsrendement, te verschijnen als LIFE Research Memorandum. 
Dewartripont, M. en G. Roland (1992), Economic reform and dynamic political constraints, Review of Economic Studies, 59, 703-730. Douglas, R. (1993), Unfinished Business, Random House.

Eichholtz, P.M.A. en C.G. Koedijk (1993a), Nieuw-Zeeland deed wat wij moeten doen, NRC Handelsblad, 21 oktober.

Eichholtz, P.M.A. en C.G. Koedijk (1993b), Een rekenkamer voor deregulering, Economisch Statistische Berichten, 1096-1099.

Fernandez, R. en D. Rodrik (1991), Resistance to reform: status quo bias in the presence of individual-specific uncertainty, American Economic Review, 1146-1155.

Galbraith, J.K. (1991), A Tenured Professor, Houghton Mifflin Company.

Geelhoed, L. (1994), 1994: Uitdagingen voor het sociaal-economische bestel, Economisch Statistische Berichten, 4-8.

Geest, L. van der (1993a), Vechteconomie, Economisch Statistische Berichten, 929.

Geest, L. van der (1993b), Subsideologie, Economisch Statistische Berichten, 1025.

Glosten, L.R. en R. Jagannathan (1994), A contingent claim approach to performance evaluation, Journal of Empirical Finance, 1, 133-161.

Klaassen J. en E. de With (1984), De waardering van vastrentende waarden in de jaarrekening van pensioenfondsen, in Klaassen (red.): Het Financiële Systeem, Stenfert-Kroese, 217-235.

Knapen, B. (1993) De situatie is emstig, niet hopeloos, NRC Handelsblad, 24 december.

Kremers, J.J.M. (1991), Naar een sterkere binnenlandse groeidynamiek, Economisch Statistische Berichten, 1128-1132.

Laffont, J.J. en J. Tirole (1993), A Theory of Incentives in Procurement and Regulation, MIT Press.

Lakonishok, J., A. Schleifer en R. Vishny (1991), Window dressing by pension fund managers, American Economic Review, 81, 227-232.

Lakonishok, J., A. Schleifer en R. Vishny (1992), The structure and performance of the money management industry, Brookings Papers on Economic Activity. 
Lehmann, B.N. en D.M. Modest (1987), Mutual fund performance evaluation: a comparison of benchmarks and benchmark comparisons, Journal of Finance, 42, 233-265.

Lintner, J. (1965), The valuation of risk assets and the selection of risky investments in stock portfolios and capital budgets, Review of Economics and Statistics, 47, 13-37.

Loo, P.D. van (1984), De beleggingen van de pensioenfondsen, Rotterdamse Monetaire Studies, nr. 13.

Magry, P.J., E.C. van Heukelom en A.J.R.M. Linders (1989), Van Camere van der Rekeninghen tot Algemene Rekenkamer, SDU uitgeverij.

Markowitz, H.M. (1952), Portfolio selection, Journal of Finance, 7, 77-91.

Olson, M. (1982), The Rise and Decline of Nations, Yale University Press.

Olson, M. (1984), Pressiegroepen en economische groei, Rotterdamse Monetaire Studies, nr. 15.

Rodrik, D. (1993), The positive economics of policy reform, American Economic Review, 83, 357-361.

Sharpe, W.F. (1964), Capital asset prices: a theory of market equilibrium under conditions of risk, Journal of Finance, 19, 425442.

Stevers, Th. A. (1979), De Rekenkamer, Stenfert Kroese.

Stigler, C. (1971), The theory of economic regulation, Bell Journal of Economics and Management Science, 2, 3-21.

The Economist (1993), Only perform, a survey of investment management.

Winston, C. (1993), Economic deregulation, days of reckoning for microeconomists, Journal of Economic Literature, 31, 12631289.

Wolff, C.C.P. (1989), Pensioenverzekering? Een financieel economische beschouwing, Oratie, Maastricht.

Wolfson, D.J. (1993), Kerntaken: van verzorgingsstaat naar transactiestaat, Oratie, Rotterdam.

Wijnbergen, S.J. van (1994), Met flexibele loonstructuur kunnen meer mensen werken, NRC Handelsblad, 1 februari. 